\title{
THE DEMOGRAPHIC SITUATION AND THE STATE OF MORBIDITY IN THE POPILATION OF THE RIVNE REGION OVER 2013-2017
}

\author{
Hushchuk I.V., Hilman A.Yu., Kulesha N.P.
}

\section{ДЕМОГРАФІІИНА СИТУАЦІЯ ТА СТАН ЗАХВОРНВАНОСТІ НАСЕЛЕННЯ РІВНЕНСЬКОÏ ОБЛАСТІ ЗА 2013-2017 РОКИ}

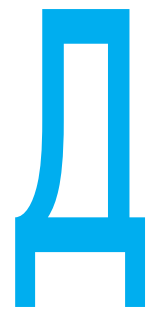

ГУЩУК І.В., ГІЛЬМАН А.Ю., КУЛЕША Н.П.

Національний університет «Острозька академія», м. Острог, Україна

Ключові слова: здоров'я, неінфекційні хвороби, загальна та первинна захворюваність. о основних типів неінфекційної захворюваності (НІЗ) належать серцево-судинні захворювання (інфаркт, інсульт), онкологічні захворювання, хронічні респіраторні захворювання (хронічна обструктивна хвороба легень, астма) і діабет [1].

На порядку денному світової спільноти на шляху сталого розвитку на період до 2030 року НІЗ визнані одними з головних перешкод. У рамках Порядку денного глави держав і урядів взяли на себе зобов'язання вжити на національному рівні рішу- чі дії, щоб до 2030 року скоротити на одну третину передчасну смертність через НІЗ за рахунок лікувально-профілактичної роботи (завдання 3.4 ЦСР) [2].

Щороку через неінфекційні захворювання вмирає 41 мільйон осіб, що становить 71\% від усіх випадків смерті у світі, з них 15 мільйонів віком від 30 до 69 років.

Понад 85\% цих «передчасних» випадків смерті припадають на країни з низьким і середнім рівнями доходів.

у структурі смертності через НІЗ найбільша частка
ДЕМОГРАФІЧНА СИТУАЦІЯ ТА СТАН

ЗАХВОРЮВАНОСТІ НАСЕЛЕННЯ

PIВНЕНСЬКОÏ ОБЛАСТІ

ЗА 2013-2017 РОКИ

Гущук І.В., Гільман А.Ю., Кулеша Н.П. Науково-дослідний центр «Екології людини та охорони громадського здоров'я» Національного університету "Острозька академія», м. Острог, Україна

Мета: дати соціально-гігієнічну оцінку стану та динамічних змін демографічної ситуації, захворюваності та поширеності хвороб серед населення Рівненської області.

Матеріали та методи. Дані, на основі яких проведено аналіз захворюваності, зібрано у 16-ти районах, обласному центрі та 2-х містах обласного значення за 20132017 роки. Для вирішення поставлених у роботі завдань було використано епідеміологічний та медико-статистичний методи. Результати. Проведено систематизацію та аналіз основних даних, які характеризують демографічну ситуацію за показниками народжуваності, смертності та природного приросту населення області. Вивчено стан загальної захворюваності і смертності в області у розрізі усіх районів та 3-х міст за основними нозологічними групами НІЗ та захворюваністю на туберкульоз. Дані систематизовано та проаналізовано у розрізі відповідних вікових груп дорослого та дитячого населення.

Висновок. В області за 2013-2017 роки показники народжуваності мають стійку тенденцію до зменшення з 15, 1 (2013) до 12,4 (2017). Відзначається зростання на 5,2\% смертності дітей до одного року, народжених живими, що вказує на необхідність покращання якості медичного обслуговування у пологових стаціонарах.

Найбільш поширеними хворобами серед населення області, як і у попередні роки, залишаються хвороби системи кровообігу, органів дихання, ендокринної системи, кровотворних органів та новоутворення. $У$ структурі смертності у нозологічних групах перше місце посідає смертність через хвороби системи кровообігу (72,4\%), на 2-му місці - новоутворення (13,9\%), на 3-му місці - травми та отруєння (5, 1\%), на 4-му - хвороби органів травлення (3,1\%), на 5му місці - хвороби органів дихання (1,6\%).

Ключові слова: здоров'я, неінфекційні хвороби, загальна та первинна захворюваність, смертність. 
THE DEMOGRAPHIC SITUATION

AND THE STATE OF MORBIDITY

IN THE POPULATION OF THE RIVNE REGION

OVER 2013-2017

Hushchuk I.V., Hilman A.Yu., Kulesha N.P.

Human Ecology and Public Health Research

Center, National University of Ostroh

Academy, Ukraine

Objective: We presented a socio-hygienic assessment of the state and dynamic changes in the demographic situation, incidence and prevalence of diseases among the population of the Rivne region.

Materials and methods: Analysis of the incidence was performed on the basis of the data collected in 16 districts, the oblast center and 2 cities of oblast significance over 20132017. In the study, we used epidemiological and medico-statistical methods.

Results: The systematization and analysis of main data, characterizing the demographic situation in terms of fertility, mortality and natural population growth of the oblast have been carried out. In the context of all regions and 3 cities, the state of general morbidity and mortality in the oblast has been studied by main nosological groups of NCD and the incidence of tuberculosis. The data have been systematized and analyzed in the context of the corresponding age groups of the adult and children's population.

Conclusion: In the region in 2013-2017, the birth rates had a steady tendency to decrease from 15.1 in 2013 to 12.4 in 2017. There is an increase of the mortality in children born alive aged under 1 year old by 5.2\%, which indicates the need to improve the quality of medical care in maternity hospitals. As in previous years, diseases of circulatory system, respiratory system, endocrine system, bloodforming organs and neoplasms are the most common ones among the population of the oblast. By nosological groups in the mortality structure, mortality of circulatory system diseases takes 1-st place (72.4\%), of neoplasms takes 2-nd place (13.9\%), of injuries and poisonings - 3-rd place (5.1\%), of diseases of digestive system - 4-th place (3.1\%), of respiratory diseases - 5-th place (1.6\%).

Keywords: health, noncommunicable diseases, general and primary morbidity, mortality. припадає на серцево-судинні захворювання, які щороку скорочують населення Землі на 17,9 мільйонів.

За ними йдуть онкологічні захворювання (9 млн. випадків), респіраторні захворювання (3,9 млн. випадків) і діабет (1,6 млн. випадків) [3].

На ці чотири групи захворювань припадає 80\% усіх випадків смерті. Вживання тютюну, низький рівень фізичної активності, зловживання алкоголем і нездорове харчування - усе це підвищує ризик смерті від неінфекційних захворювань.
Мета даної роботи полягала у соціально-гігієнічній оцінці стану та динамічних змін демографічної ситуації, захворюваності й поширеності хвороб серед населення Рівненської області.

Матеріали та методи. Дані, на основі яких проведено аналіз захворюваності, зібрано у шістнадцяти районах, обласному центрі та двох містах обласного значення за 2013-2017 роки. Для вирішення поставлених у роботі завдань було використано епідеміологічний та медико-статистичний методи.
Результати. За даними Головного управління статистики [4], у Рівненській області станом на 01.01. 2018 року чисельність наявного населення становила 1160,6 тисяч осіб, у тому числі міське населення 550,9 тисяч осіб $(47,5 \%)$, сільське - 609,7 тисяч осіб (52,5\%). Середня тривалість життя в області дещо вища, ніж в Україні загалом і становить 71,6 років (чоловіки - 66,1 років, жінки 77,1 років).

Динаміку демографічних процесів в області представлено у таблиці 1.

\section{Динаміка демографічних процесів у Рівненській області}

Таблиця 1

\begin{tabular}{|l|c|c|c|c|c|c|}
\hline \multirow{2}{*}{\multicolumn{2}{|c|}{ Показник, на 1000 осіб }} & \multicolumn{4}{|c|}{ Значення показників за роками } & \multirow{2}{*}{$\begin{array}{c}\text { Зміни у 2017 р. (+/-) } \\
\text { порівняно з 2013 р. }\end{array}$} \\
\cline { 2 - 6 } & 2013 & 2014 & 2015 & 2016 & 2017 & $-2,7$ \\
\hline Народжуваність & 15,1 & 14,8 & 13,9 & 13,5 & 12,4 & 0 \\
\hline Загальна смертність & 12,6 & 12,7 & 12,7 & 12,5 & 12,6 & $-2,7$ \\
\hline Природний приріст (скорочення) & $+2,5$ & $+2,1$ & $+1,2$ & $+1,0$ & $-0,2$ & $+0,41$ \\
\hline $\begin{array}{l}\text { Смертність дітей до 1 року } \\
\text { на 1000 народжених живими }\end{array}$ & 7,85 & 8,02 & 8,51 & 8,31 & 8,26 & + \\
\hline
\end{tabular}


Згідно 3 отриманими даними видно, що за досліджуваний період показники народжуваності мають стійку тенденцію до зменшення з 15,1 у 2013 р. до 12,4 у 2017 р. Показники загальної смертності мали незначні коливання і у порівнюваний період залишилися без змін, але у звязку зі зниженням народжуваності у 2017 році зафіксовано від'ємний природний приріст $(-0,2)$. Відзначається збільшення на 5,2\% смертності дітей до одного року, які народжені живими, що вказує на необхідність покращання якості медичного обслуговування у пологових стаціонаpax.

Динаміку первинної захворюваності та поширеності хвороб серед населення Рівненщини за останні 5 років наведено у таблиці 2.

Як видно з наведених даних, на тлі незначних коливань захворюваності серед усього населення показник захворюваності дорослого населення за досліджуваний період зменшився на 5,2\%, але серед дітей і підлітків у вікових групах до 14 років та 15-17 років показник збільшився відповідно на 2,4\% та $18,3 \%$.

Поширеність захворювань має незначну тенденцію до збільшення.

На даний час працівниками НДЦ «Екології людини та охорони громадського здоров'я» Національного університету «Острозька академія» проводиться поглиблене вивчення стану загальної та первинної захворюваності серед дорослого та дитячого населення за основними номенклатурами хвороб відповідно до МКX-10 (12 нозологічних груп) за період 2008-20018 роки.

Найбільш поширеними серед населення області, як і у попередні роки, залишаються серцево-судинні та судинно-мозкові хвороби.

Найбільш значимими показниками поширеності $\epsilon$ дані щодо хвороб системи кровообігу, які 2017 року становили 489,8 випадків на 1000 осіб. Далі найбільш суттєві показники поширеності характеризують хвороби органів дихання (381,2 випадків на 1000 осіб), хвороби ендокринної системи (138,2 випадків на 1000 осіб) та хвороби крови і кровотворних органів $(18,9$ випадків на 1000 осіб). При цьому привертає увагу поширеність серед населення новоутворень, яка має стійку тенденцію до збільшення протягом останніх років і становить 47,1 випадків на 1000 осіб. При цьому смертність через новоутворення посідає друге місце після хвороб системи кровообігу.

Динаміку поширеності серед населення області зазначених хвороб системи кровообігу, органів дихання, органів травлення, ендокринної системи, крови та кровотворних органів, новоутворень за останні 5 років наведено у таблиці 3.

Таблиця 2

\section{Динаміка захворюваності та поширеності хвороб серед населення} Рівненської області (на 1000 осіб)

\begin{tabular}{|l|c|c|c|c|c|}
\hline \multicolumn{1}{|c|}{ Категорія населення } & 2013 & 2014 & 2015 & 2016 & 2017 \\
\hline Захворюваність усього населення області & 756,2 & 745,1 & 757,3 & 758,7 & 751,5 \\
\hline Дорослі & 569,0 & 549,4 & 553,9 & 557,2 & 539,2 \\
\hline Підлітки (15-17 років) & 1308,8 & 1285,1 & 1424,4 & 1513,3 & 1548,2 \\
\hline Діти (до 14 років) & 1371,1 & 1341,2 & 1404,6 & 1381,9 & 1404,6 \\
\hline Поширеність & 1870,4 & 1865,9 & 1908,1 & 1903,5 & 1890,8 \\
\hline
\end{tabular}

Поширеність хвороб (на 1000 осіб)

Таблиця 3

\begin{tabular}{|l|c|c|c|c|c|}
\hline \multicolumn{1}{|c|}{ Клас хвороб } & 2013 & 2014 & 2015 & 2016 & 2017 \\
\hline Система кровообігу & 489,7 & 491,0 & 499,8 & 496,6 & 489,8 \\
\hline Органи дихання & 362,0 & 365,4 & 380,5 & 388,6 & 381,2 \\
\hline Ендокринна система & 136,4 & 138,0 & 138,9 & 137,1 & 138,2 \\
\hline Кров і кровотворні органи & 20,3 & 20,0 & 19,5 & 19,5 & 18,9 \\
\hline Новоутворення & 39,2 & 39,8 & 43,3 & 45,2 & 47,1 \\
\hline
\end{tabular}


ДЕМОГРАФИЧЕСКАЯ СИТУАЦИЯ

И СОСТОЯНИЕ ЗАБОЛЕВАЕМОСТИ

НАСЕЛЕНИЯ РОВЕНСКОЙ ОБЛАСТИ

ЗА 2013-2017 ГОДЫ

Гущук И.В., Гильман А.Ю., Кулеша Н.П.

Научно-исследовательский центр

«Экологии человека и охраны

общественного здоровья» Национального

университета «Острожская академия»,

г. Острог, Украина

Цель. Дать социально-гигиеническую оценку состояния и динамических изменений демографической ситуации, заболеваемости и распространенности болезней среди населения Ровенской области.

Материалы и методы. Данные, на основе которых проведен анализ заболеваемости, собраны в 16-ти районах, областном центре и 2-х городах областного значения за 2013-2017 годы. Для решения поставленных в работе задач были использованы эпидемиологический и медико-статистический методы.

Результаты. Проведены систематизация и анализ основных данных, характеризующих демографическую ситуацию по показателям рождаемости, смертности и естественного прироста населения области. Изучено состояние общей заболеваемости и смертности в области в разрезе всех районов и 3-х городов по основным нозо- логическим группам НИЗ и заболеваемости туберкулезом. Данные систематезированы и проанализированы в разрезе соответствующих возрастных групп взрослого и детского населения.

Вывод. В области за 2013-2017 годы показатели рождаемости имеют устойчивую тенденцию к уменьшению с 15, 1 (2013) до 12,4 (2017). Отмечается рост смертности детей до одного года, рожденных живыми, на 5,2\%, что указывает на необходимость улучшения качества медицинского обслуживания в родильных стационарах. Наиболее распространенными болезнями среди населения области, как и в предыдущие годы, остаются болезни системы кровообращения, органов дыхания, эндокринной системы, кроветворных органов и новообразования. В структуре смертности по нозологическим группам 1 место занимает смертность от болезней системы кровообращения (72,4\%), на 2-м месте смертность от новообразований (13,9\%), на 3-м месте - от травм и отравлений (5,1\%), на 4-м - от болезней органов пищеварения (3,1\%), на 5-м - смертность от болезней органов дыхания (1,6\%).

Ключевые слова: здоровье, неинфекционные болезни, общая и первичная заболеваемость, смертность.
За підсумками 2017 року, у структурі смертності у нозологічних групах 1 місце належить смертності через хвороби системи кровообігу, яка становить $72,4 \%$ від загальної смертності. Вище середньообласного показника смертність відзначалася у Демидівському (82,1\%), За- річненському $(81,3 \%)$, Острозькому $(79,8 \%)$, Рокитнівському $(78,1 \%)$, Радивилівському $(76,9 \%)$ та Дубенському $(76,3 \%)$ районах. Друге місце посідають показники смертності через новоутворення, які загалом дорівнюють $13,9 \%$. При цьому в окремих містах та районах вони визначаються на таких рівнях: м. Вараш $25,6 \%$, м. Рівне - 24\%, м. Дубно - 14,6\%, Рівненський район - $16,1 \%$, Сарненський - 15,5\%, Млинівський та Радивилівський - по $14,4 \%$. Наступні місця посідають смертність через травми та отруєння $(5,1 \%)$,

Ситуація з онкологічними захворюваннями та туберкульозом (на 100 тис. осіб) у Рівненській області за 2013-2017 роки

\begin{tabular}{|l|c|c|c|c|c|}
\hline \multicolumn{1}{|c|}{ Показник } & 2013 & 2014 & 2015 & 2016 & 2017 \\
\hline $\begin{array}{l}\text { Захворюваність на онкопатологію, } \\
\text { на 100 тис. осіб }\end{array}$ & 277,8 & 269,2 & 251,3 & 265,5 & 256,1 \\
\hline $\begin{array}{l}\text { Відсоток 4 стадії онкозахворювань } \\
\text { (серед вперше виявлених хворих) }\end{array}$ & 12,7 & 12,5 & 13,2 & 13,4 & 13,9 \\
\hline $\begin{array}{l}\text { Поширеність злоякісних новоутворень, } \\
\text { на 100 тис. осіб }\end{array}$ & 1759,6 & 1805,0 & 1871,2 & 1910,4 & 1869,3 \\
\hline $\begin{array}{l}\text { Захворюваність на активний туберкульоз, } \\
\text { на 100 тис. осіб }\end{array}$ & 62,9 & 55,8 & 54,8 & 52,6 & 43,5 \\
\hline $\begin{array}{l}\text { Відсоток занедбаних форм туберкульозу } \\
\text { (серед вперше виявлених хворих) }\end{array}$ & 21,8 & 25,3 & 31,9 & 29,9 & 33,5 \\
\hline $\begin{array}{l}\text { Поширеність (хворобливість) на активний } \\
\text { туберкульоз, на 100 тис. осіб }\end{array}$ & 111,9 & 88,1 & 83,5 & 81,2 & 68,0 \\
\hline
\end{tabular}


злоякісних новоутворень становить 1869,3 на 100 тис. осіб, а первинна захворюваність - 256, 1 на 100 тис. осіб. За п'ять останніх років поширеність злоякісних новоутворень серед населення області зросла на 6,2\%. У структурі локалізацій онкопатологій у виявлених вперше і взятих на облік онкохворих найбільшу частку мають молочна залоза - 9,6\%, шкіра - 8,2\% та легені - 7,6\%.

Насторожує факт стійкого зростання показників щодо запущених форм ракових захворювань на 6,2\%, що, 3 одного боку, може вказувати на недостатній рівень організації та проведення профілактичних оглядів, запровадження регіональних скринінгових програм, ведення освітньо-профілактичної роботи, низький рівень настороженості населення до онкологічних хвороб, а 3 іншого, можливо - про покращання діагностики. Це питання потребує посилення уваги з боку керівних структур охорони здоров'я області.

Протягом останніх п'яти років в області спостерігається стабілізація показників, які характеризують ураженість населення активними формами туберкульозу. Поширеність (хворобливість) активного туберкульозу знизилася на 39\%, захворюваність - на 31\%.

Також знизилася і смертність серед населення через туберкульоз.

Ситуацію з онкологічними захворюваннями та туберкульозом в області наведено у таблиці 4

\section{Висновки}

1. За період 2013-2017 рр. в області показники народжуваності мають стійку тенденцію до зменшення 3 15, 1 (2013) до 12,4 (2017). Показники загальної смертності мали незначні коливання і у порівнюваний період залишилися без змін, але у звязку зі зниженням народжувано- сті у 2017 році зафіксовано від'ємний природний приріст $(-0,2)$. Відзначається зростання на 5,2\% смертності дітей до одного року, народжених живими, що вказує на необхідність покращання якості медичного обслуговування у пологових стаціонарах.

2. Найбільш поширеними хворобами серед населення області, як і у попередні роки, залишаються хвороби системи кровообігу, органів дихання, ендокринної системи, кровотворних органів та новоутворення.

3. За п'ять останніх років поширеність злоякісних новоутворень серед населення області збільшилася на 6,2\%. у структурі локалізацій онкопатологій серед виявлених вперше і взятих на облік онкохворих найбільшу частку мають молочна залоза $(9,6 \%)$, шкіра $(8,2 \%)$, легені $(7,6 \%)$.

4. У структурі смертності у нозологічних групах провідні місця посідають смертність через хвороби системи кровообігу $(72,4 \%)$, смертність через новоутворення $(13,9 \%)$, смертність через травми та отруєння (5,1\%), смертність через хвороби органів травлення (3,1\%) та смертність через хвороби органів дихання $(1,6) \%$.

\section{ЛІТЕРАТУРА}

1. Резолюция Генеральной Ассамблеи ООН.

Преобразование нашего мира: Повестка дня в области устойчивого развития на период до 2030 года. 2015. 44 с. URL : http://www. un.org/ru/documents/ods. asp? $m=A / R E S / 70 /$ $1]$.

2. Цілі сталого розвитку: Україна. Національна доповідь, 2017. К. : Міністерство економічного розвитку і торгівлі України, 2017. C. 83-89. URL : http://un.org.ua/images/SDG s_NationalReportUA_ Web_1.pdf. 
3. ВОЗ. Неинфекционные заболевания. URL :

https://www. who.int/topics/ch ronic_diseases/ru/ (Дата обращения 20.12.2019).

4. Доповідь про стан навколишнього природного середовища у Рівненській області за 2017 рік.

2018. 236 c. URL :

http://www.ecorivne.gov.ua/r eport_about_environment.

5. Волощук О.В.,

Антомонов М.Ю., Гущук І.В.

Аналіз рівня захворюваності населення Рівненської області. Довкілля та здоров 'я. 2017 . № 1 (81). C. 27-31.

\section{REFERENCES}

1. Resolution of the UNO General Assembly. Transforming our world: the 2030 Agenda for Sustainable Development. 2015. 44 p. URL : http://www.un.org/ru/documents/ods.asp?m=A/RES/70/ $1]$.

2. Ministry of Economic Development and Trade of Ukraine. Цілі сталого розвитку: Україна. Національна доповідь, 2017. Tsili staloho rozvytku: Ukraina. Natsionalna dopovid [Sustainable Development Goals: Ukraine. National Report, 2017]. Kyiv ; 2017 : 83-89. URL : http://un.org. ua/images/SDGs_NationalRe portUA_Web_1.pdf (in Ukrainiān).

3. WHO. Noncommunicable diseases. URL : https://www. who.int/topics/ch ronic diseases/ru/ (Дата обращения 20.12.2019).

4. Доповідь про стан навколишнього природного середовища у Рівненській області за 2017 рік. 2018. 236. URL : http://www. ecorivne.gov.ua/report _about_environment (in Ükrainian).

5. Voloshchuk O.V., Antomonov M.Yu. and Hushchuk I.V. Dovkillia ta zdorovia (Environment and Health). $2017 ; 1$ (81) : 27-31 (in Ukrainian).

Надійшло до редакції 12.10.2019
УДК 582.282.23:57.017.4:541. https://doi.org/10.32402/

4:616.37-008.64 dovkil2020.01.039

\section{SENSITIVITY TO SYNTHETIC AROMACYCLIC AMINO SPIRITS OF CANDIDA ISOLATED IN THE PATIENTS WITH TYPE I DIABETES \\ Osypchuk N.O., Nastenko V.B., Shyrobokov V.P., Korotkyi Yu.v.}

ЧУТЛИВІСТЬ ДО СИНТЕТИЧНИК АРОМАЦИКЛІЧНИХ
АМПНОСПИРТВ ІЗОЛЯТІВ САМОПОА, ЩО ВИДІЛЕН
ВІД ПАЦІЕНТІВ З ЦУКРОВИМ ДІАБЕТОМ 1-2О ТИПУ

\author{
1ОСИПЧУК Н.О., \\ 1НАСТЕНКО В.Б., \\ 1 ШИРОБОКОВ В.П., \\ 2КОРОТКИЙ Ю.В. \\ м. Київ, Україна \\ 2Інститут органічної хімії
}

1НМКУ ім. О.О. Богомольця,

НАН України, м. Київ, Україна а останні десятиліття кандидоз значно поширився в усьому світі і $€$ важливою причиною захворюваності та смертності, зокрема серед тяжкохворих пацієнтів [1].
ЧУТЛИВІСТЬ ДО СИНТЕТИЧНИХ АРОМАЦИКЛІЧНИХ AМIHОСПИРТІВ ІЗОЛЯТІВ CANDIDA, ЩО ВИДІЛЕНI ВІД ПАЦІЕНТІВ З ЦУКРОВИМ ДІАБЕТОМ 1-ГО ТИПУ 1Осипчук Н.О., 'Настенко В.Б., 'Широбоков В.П., 2Короткий Ю.В.

1нМУ ім. О.О. Богомольця, м. Київ, Україна

2/нститут органічної хімії НАН України, м. Київ, Україна

Похідні ароматичних аміноспиртів є перспективною групою речовин з антифунгальним ефектом.

Мета роботи - дослідити чутливість клінічних ізолятів дріжджоподібних грибів роду Candida, виділених із суббіотопів ротової порожнини від хворих на цукровий діабет 1-го типу, до синтетичних аромациклічних аміноспиртів та комерційних антимікотиків.

Матеріали і методи. У роботі використано бібліосемантичний, мікроскопічний, мікологічний, статистично-аналітичні методи. Результати і обговорення. Виділено 90 ізолятів представників роду Candida. Частота виділення дріжджоподібних грибів у біотопі ротової порожнини становила 66, 1\%. Рівень орального кандидоносійства серед пацієнтів з ЦД 1-го типу становив 5, 1\%. Серед представників роду Candida у складі суббіотопів порожнини рота виявлено C. albicans, C. glabrata, C. krusei, C. tropicalis, C. Kefyr, при цьому 67,8\% становить C. albicans, 10,0\% - C. glabrata, 16,7\% - C. krusei, 3,3\% - C. tropicalis, C. kefyr - 2,2\%. Серед сполук найвищу активність мала Кс22, яка у концентрації 0,24-0,97 мкг/мл пригнічувала 59,0\% штамів. Серед комерційних антимікотиків найвищу активність проявив амфотерицин В. Флуконазол та інтраконазол характеризувалися неефективністю щодо клінічних штамів.

Висновок. Частота виділення дріжджоподібних грибів у біотопі ротової порожнини у пацієнтів з ЦД 1-го типу становила 66,2\%. Серед ідентифікованих кандид в усіх досліджуваних суббіотопах ротової порожнини превалювала C. albicans (67,8\%). Клінічні ізоляти стійкі до ітраконазолу (100\%) та флуконазолу (81,7\%). Усі ізоляти виявилися чутливими до амфотерицину В (75,3\%). Похідні алкіл(арилоксиетокси)діалкіламінопропанолу мали високу антикандидозну активність щодо усіх видів клінічних ізолятів.

Ключові слова: кандидоз, Candida, аміноспирти, ітраконазол, флуконазол, амфотерицин В.

(С Осипчук Н.О., Настенко В.Б., Широбоков В.П., Короткий Ю.В. СТАТТЯ, 2020. 